\section{Effect of despotic leadership on counterproductive behavior: the role of reduced organization-based self-esteem and emotional stability}

\author{
Muhammad Anwar ul Haq ${ }^{1}$ \\ Mirza Ashfaq Ahmed ${ }^{2}$ \\ Sobia Shabeer ${ }^{3}$ \\ Shaista Khalid ${ }^{4}$ (D)
}

\section{Abstract}

Purpose: The aim of this paper was to examine the effect of despotic leadership behavior on followers' counterproductive behavior. It was also hypothesized that the effect would be mediated by reduced organization-based self-esteem (ROBSE) and moderated by employee emotional stability. We draw upon the conservation of resources perspective and social exchange theory.

Theoretical framework: We draw upon social exchange theory.

Design/methodology/approach: The setting of the study was SMEs (small and medium enterprises) in the Gujranwala Division of Pakistan. Time-lagged data were collected from 227 supervisor-subordinate dyads. Structural equation modeling was applied to test the direct and mediating effects. Interaction moderation was performed using Hayes' PROCESS macro in SPSS.

Findings: The findings suggest that despotic leadership has a positive effect on counterproductive behavior. Reduced organization-based self-esteem partially mediates the influence of despotic leadership on counterproductive behavior. Similarly, emotional stability moderates the impact of despotic leadership on counterproductive behavior.

Research Practical \& Social Implications: The phenomenon of despotic leadership is not new in organizations; however, it has only recently attracted interest from researchers. It is a good time to empirically investigate the impacts this leadership style can have on subordinates.

Originality/Value: For the first time, it is confirmed by our results that despotic

1. University of Gujrat, Department of Management, Gujrat, Pakistan

2. University of Gujrat, Department of Management, Gujrat, Pakistan

3. University of Gujrat, Department of Management, Gujrat, Pakistan

4. University of Sargodha, Department of Education, Sargodha, Pakistan

How to cite:

Anwar ul Haq, M., Ahmed, M. A., Shabbir, S., Khalid, S. (2021). Effect of despotic leadership on counterproductive behavior: the role of reduced organization-based selfesteem and emotional stability. Revista Brasileira de Gestão de Negócios, 23(3), p.454-469.
Received on:

08/06/2019

Approved on:

$01 / 18 / 2021$

Responsible Editor:

Prof. Dr. Jesús Barrena

\section{Evaluation process:}

Double Blind Review

Reviewers:

Ali Ender Altunoglu; Cem Tanova

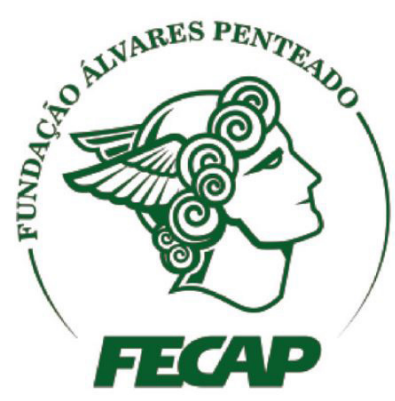

Revista Brasileira de Gestáo de Negócios

https://doi.org/10.7819/rbgn.v23i3.4116 
leaders' behavior lowers subordinates' self-esteem and causes them to engage in counterproductive behavior, except those who have high levels of emotional stability. The study sheds light on the ill effects of despotic leaders on followers.

Keywords: despotic leadership, counterproductive behavior, reduced organizationbased self-esteem, emotional stability

\section{Introduction}

Leadership has always fascinated organizational researchers because of the traditionally positive connotation attached to it as a construct, and because of its implications for performance at the individual, group, and organizational levels. The research efforts have focused more on the positive aspects of leadership behavior while neglecting the negative side. However, for the last few years, the research has started to tilt towards the darker side of leadership, thus introducing a paradigm shift in the studies on leadership (Karakitapoğlu-Aygün \& Gumusluoglu, 2013). This has been further driven by scandals such as Enron and WorldCom (Naseer, Raja, Syed, Donia, \& Darr, 2016). These scandals have pointed to the need to understand how the ugly side of a leader can be harmful for the organization. Furthermore, Griffin and O'Leary-Kelly (2004) suggest that growing interest in the negative side of leadership reflects the ushering in of a critical thinking movement in the leadership literature.

The organizational literature uses various terminologies to indicate the negative side of leadership, such as "abusive supervision" (Tepper, 2007), "tyrannical leadership" (Ashforth, 2009), "destructive leadership" (Einarsen, Aasland, \& Skogstad, 2007), "toxic leadership" (Frost, 2004), and "despotic leadership" (Aronson, 2001). This paper focuses on despotic leadership since it covers the important aspects of a negative leadership style and is also an under-researched area in organizational sciences (Erkutlu \& Chafra, 2018; Schyns \& Schilling, 2013). Despotic leadership refers to a leader's inclination for personal dominance and authoritative behavior that serves their own self-interest and self-aggrandizement and is based on manipulation (Aronson, 2001; De Hoogh \& Den Hartog, 2008). Such leaders are arrogant, unforgiving, bossy, and focus on achieving supremacy over their followers (Naseer et al., 2016). With such qualities they negatively influence their followers and hamper organizations and individuals in achieving their goals (Karakitapoğlu-Aygün \& Gumusluoglu, 2013).

Despotic leadership has been studied in relation to various constructs, such as psychological distress, work-family conflict, emotional exhaustion, turnover intentions, lower organizational performance, decreased commitment, and job dissatisfaction (Schyns \& Schilling, 2013; Tepper, 2000). Despite its potential to explain followers' counterproductive behavior, this still needs to be empirically validated (Erkutlu \& Chafra, 2018; Karakitapoğlu-Aygün \& Gumusluoglu, 2013). Counterproductive behavior refers to when an employee intentionally behaves against the legitimate interests of their organization (Gruys \& Sackett, 2003). Some scholars (Collins \& Jackson, 2015; Schyns \& Schilling, 2013) argue that negative leadership is one of the major antecedents of counterproductive organizational behaviors and call for further research into it.

In order to explain the effect of despotic leadership on counterproductive behavior, this paper uses social exchange theory as a basis. Social exchange is a sequence of give and take between two parties. These two-way mutual exchanges obligate both parties to reciprocate any course of action initiated by one of them (Blau, 1964). A despotic leader, through their behavior, has a negative influence over their followers. These followers would, in turn, reciprocate with actions directed towards their leaders, work, and organization. Therefore, if a leader adopts a despotic behavior, the followers would reciprocate in a similar way. Investigating the effect of despotic leadership on counterproductive behavior is the first objective of this study.

There are different intervening mechanisms in between despotic leadership and counterproductive behavior. In this study, we theoretically contend that no follower would engage in counterproductive behavior unless they experience a reduction in their organizationbased self-esteem. Leaders' actions can be very detrimental to the self-esteem of their followers in an organization. 


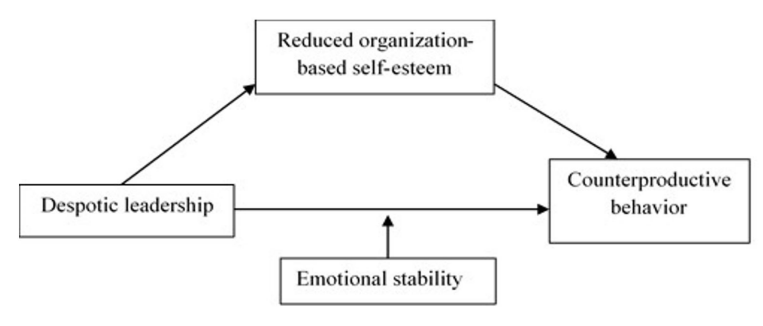

Figure 1. Research Framework

The latter may feel that their self-esteem is shattered or raised by the behavior of their leaders. A despotic leader would reduce followers' self-esteem. In this study, we call this construct "reduced organization-based self-esteem." With this, we make two contributions: first, we introduce ROBSE as a new construct in the literature; second, we include it as a mediating mechanism (Figure 1).

Furthermore, we study the moderating effect of emotional stability on the relationship between despotic leadership and counterproductive behavior (Figure 1). This is in response to the gap highlighted by Vries (2018) and Tepper (2007). They proposed that future studies should investigate the interactive effects of personality traits, such as emotional stability, to understand the impact of negative leadership styles on job outcomes. According to Judge and Bono (2001), emotional stability is the tendency to remain calm, confident, and secure. Those with high levels of emotional stability are free from negative emotions. Smith and Williams (1992) argue that individuals with higher levels of emotional stability are less likely to react strongly to tense situations. They are proactive and adept at dealing with problems (Heppner, Cook, \& Wright, 1995). Emotionally stable individuals perform their jobs better by remaining rational and being able to overcome negative emotions (Judge \& Bono, 2001). Due to such conceptual characteristics, emotional stability is a relevant moderator in the aforementioned relationship.

This study is important for the literature on leadership in the following ways. First, it fills a knowledge gap by examining the relationship between despotic leadership and counterproductive behavior. Previous studies have found that an unethical leadership style causes organizational deviance (Erkutlu \& Chafra, 2018). This study intends to be one of the first to investigate the association between despotic leadership and counterproductive behavior. Second, this study investigates the process through which despotic leadership affects counterproductive behavior by investigating the intervening role of reduced organization-based selfesteem (Carlson, Ferguson, Perrewé, \& Whitten, 2009). For this it uses social exchange theory (SET) as the key theoretical perspective. Lastly, this research adds to the literature by examining the interaction between leaders' despotic behavior and followers' emotional stability and how this affects counterproductive behavior.

\section{Theoretical Background and Hypotheses Development}

\section{I Despotic leadership and counterpro- ductive behavior}

Despotic leaders exhibit behaviors such as dominance and supremacy and focus on their own selfinterests. They are bossy, manipulative, unforgiving, and arrogant (Howell \& Avolio, 1992). Despotic leaders demand unquestioning submission and compliance, they are selfish, and they behave callously. They are always demanding and controlling of subordinates (Schilling, 2009). Despotic leaders are self-centered, morally corrupt, and have unethical work standards (De Hoogh \& Den Hartog, 2008). In contrast to destructive, tyrannical, undermining, and abusive leadership where leaders show antagonistic, humiliating, and oppressive behaviors towards their followers, despotic leaders are egoistic and manipulate their subordinates for personal gain. Despotic leaders do not behave in a social and ethically constructive manner and are deceitful towards their followers. They do not promote organizational interests but instead engage in morally incorrect and fraudulent behaviors (Aronson, 2001; De Hoogh \& Den Hartog, 2008).

Despotic behavior by leaders has negative implications for followers' productivity, workplace behaviors, as well as their personal life. According to Naseer et al. (2016), despotic leadership negatively affects subordinates' job performance. Since the leaders are the representatives of an organization, employees reciprocate the despotic behaviors of leaders, which are harmful to both these leaders and the organization. They reduce their performance as a result. Likewise, they engage in deviant behaviors in response to their leaders' despotic behavior (Erkutlu \& Chafra, 2018). Such followers lower their performance, engage in deviant behavior, and withhold their involvement in extra-role 
activities because they find it hard to engage with their despotic leaders (Erkutlu \& Chafra, 2018; Naseer et al., 2016). Apart from productivity, despotic leadership also affects the personal lives of employees, causing work-family conflict and lowering life satisfaction. Negative leadership behaviors have been recognized as workplace stressors. They also have negative effects on workers' personal lives (Nauman, Fatima, \& Haq, 2018). In this study, we are specifically interested in how despotic leaders affect counterproductive behaviors in the workplace, since the evidence is lacking in this regard.

Counterproductive behaviors are the volitional acts carried out by organizational members that potentially harm the legitimate interests of an organization or its stakeholders (Sackett \& DeVore, 2002). Employees' counterproductive behavior can take the form of property theft, violations, withdrawal/absence, aggression, substance abuse, and production deviance (Spector et al., 2006). According to Robinson and Bennett (1995), counterproductive behaviors are behaviors that employees purposefully adopt to cause damage to their organization, ranging from damaging the organization's property to performing below the benchmark in terms of both quality and quantity. By voluntarily engaging in counterproductive behavior, employees violate the established social and organizational norms. Such behaviors can be either overt, such as aggression and theft, or covert, such as disregarding orders and deliberately making mistakes (Fida et al., 2015).

Given the conceptual domains of despotic leadership and counterproductive behavior, social exchange theory can best help explain the linkage between the two. Social exchange encompasses a process of give and take between two parties (Emerson, 1976). Such exchanges, whether positive or negative, develop a mutual obligation. The exchange phenomenon is two-way and the way it works depends on how both the parties take part in the phenomenon (Blau, 1964). The longer the phenomenon takes place between the two parties, the greater the chances of establishing trust, dedication, and a shared obligation (Emerson, 1976). To strengthen mutual commitment, the parties need to follow the norms of the exchange process, i.e. the norms of reciprocity (Gouldner, 1960). In mutual exchange commitments, the actions of one party elicit reactions from the other. If one party adopts a harmful course of action, the other reciprocates in a similar way. Similarly, if one party acts favorably, reciprocation occurs in the same manner. Hence, social exchange theory explains both positive and negative reciprocation (Kelley, 1968).

Under the aegis of social exchange theory, it is contended that managers and employees develop an exchange relationship. The behavior of employees is always contingent upon the behavior of their managers (Cropanzano \& Mitchell, 2005). Employee reciprocation, whether positive or negative, depends on the behavior they experience. Leaders who are despotic towards their followers make those followers feel less respected and valued in the organization and cause them to engage in counterproductive behaviors (Thau, Derfler-Rozin, Pitesa, Mitchell, \& Pillutla, 2015). Despotic leaders also rank low on the ethical continuum and therefore treat their subordinates unfavorably (Naseer et al., 2016). In return, these subordinates feel disengaged and do not exert efforts to benefit the organization. Despotic leaders use their influence to advance their self-interests and their subordinates also redirect their efforts to fulfill their own personal agendas at the cost of the organization (Erkutlu \& Chafra, 2018). Furthermore, despotic leaders antagonize their followers because of power differences, causing these followers to engage in retaliatory behaviors. Such retaliation goes against the interests of the leaders and the organization as it results in counterproductive behaviors (Tepper et al., 2009). Hence, we propose the following:

H1: Despotic leadership has a positive effect on counterproductive behavior.

\subsection{Mediating role of reduced organization- based self esteem}

According to Pierce and Gardner (2004), organization-based self-esteem (OBSE) relates to an individual's feelings towards their organization, in which they believe they are capable, important, and a worthwhile part of the organization. OBSE is a reflection of selfperception. Such self-perception defines an individual's adequacy as a member of an organization. Those with high self-esteem develop the belief that "I count around here." They tend to satisfy their needs through their role in the organization (Korman, 1970). Pierce, Gardner, Cummings, and Dunham (1989) add that high levels of self-esteem are indicated when an organizational member states that "I make a difference around here" and "I am an important part here." For the purposes of this study, we coin and introduce the term "reduced organization-based self-esteem," which is defined as the absence of feelings 
that make individuals feel they are a significant part of the organization.

OBSE has been employed as an underlying mechanism in various studies to explain the relationship between various antecedent and outcome variables. For instance, Lee and Peccei (2007) found that organizational support effects followers' affective commitment through the process of organization-base self-esteem. Similarly, Ferris, Brown, and Heller (2009) observed that OBSE fully mediates the relationship between organizational support and deviance. In a recent study, Norman, Gardner, and Pierce (2015) verified that OBSE mediates the relationship between various managerial roles and employee outcomes.

According to Pierce and Gardner (2004), changes in the working environment are likely to change employees' organization-based self-esteem. This may increase or decrease as the environmental antecedents in the organization change. Since organization-based selfesteem is a conceptualization of self, it plays a major role in shaping the cues and feedback received from significant others such as role models, mentors, and bosses (Baumeister, 1999). Therefore, in an organizational context a leader's behavior is an important antecedent for enhancing or reducing a follower's self-esteem (Norman et al., 2015).

A leader's behavior is an important determinant of their follower's sense of self-worth (Norman et al., 2015). Despotic leaders are exploitative, dominant, and authoritarian (Aronson, 2001). They are characterized by an unforgiving, arrogant, and demanding style (Howell $\&$ Avolio, 1992; Schilling, 2009). They exercise power and control over their followers. They lack honesty and morals standards. Moreover, they do not empower their followers and advance their own interests (De Hoogh \& Den Hartog, 2008). According to Morgeson, DeRue, and Karam (2010), the despotic behaviors of leaders change their perceptions of their followers. Continued despotic behaviors lead followers to believe that they do not "count around here."

Pierce et al. (1989) theorized that two categories of employee experiences in organizations shape their sense of organizational worthiness: (1) experiences of the work environment structure and (2) treatment from significant others. Each of these experiences are to a certain degree influenced by the leader. First, an employee's experience of their work environment structure influences their OBSE. A loosely structured environment which ensures employee participation in the decision-making process signals to employees that they are valued (Korman, 1971). In contrast, in a tightly structured environment, where leaders impose various barriers to employees engaging in self-direction, employees' sense of self-worth diminishes (Gardner \& Pierce, 2016). Despotic leaders also limit the participation of their team members in the decisionmaking process (De Hoogh \& Den Hartog, 2008), causing a reduction in their OBSE. Second, employees develop self-esteem based on the treatment they receive from significant others such as leaders and colleagues. Positive cues received from significant others in the workplace enhance an employee's self-evaluation (Korman, 1971). Managers who constantly provide feedback and appreciate their team members for their accomplishments enhance their followers' self-esteem (Gardner, Dyne, \& Pierce, 2004). In contrast, a directive manager controls the activities of their followers. Such managers evaluate their followers as being incompetent, causing a reduction in their self-esteem (Vecchio, 2000). Schilling (2009) argues that the way despotic leaders exercise power over and treat their followers lowers employees' self-esteem.

Furthermore, in a meta-analytic investigation, Bowling, Eschleman, Wang, Kirkendall, and Alarcon (2010) found that organization-based self-esteem predicts various work-related outcomes. A higher level of OBSE was related with job satisfaction and affective commitment, whereas reduced OBSE was found to be related with outcomes such as turnover and absenteeism intentions. In a recent empirical study, Chan, Huang, Snape, and Lam (2013) observed that OBSE has a positive relationship with task performance and that it mediates between paternalistic leadership and task performance. In an earlier investigation, Ferris et al. (2009) proved that OBSE mediates between organizational support and organizational deviance. They found that low levels of OBSE are directly related with organizational deviance. Chan et al. (2013) found that negative forms of leader behavior reduce followers' self-esteem. Baumeister, Dewall, Ciarocco, and Twenge (2005) identified that reduced self-esteem impairs an individual's self-regulatory ability. Employees with impaired self-regulation are more likely to adopt counterproductive behaviors in the workplace.

In the preceding discussion, it was established that despotic leadership reduces followers' organizationbased self-esteem. In turn, reduced organization-based self-esteem translates into follower counterproductivity in the workplace. Therefore, it can be argued that there 
is an underlying mechanism between despotic leadership and counterproductive behavior. Norman et al. (2015) believe followers find that directive and demanding leaders constrain their sense of worth and competence, hence leading to a reduction in OBSE. As mentioned above, reduced OBSE results in negative work outcomes. Despotic leaders engage in demanding behavior, causing reduced OBSE and increasing the possibility of counterproductivity in return. Based on the above theorization, the following hypothesis is proposed:

H2: Reduced OBSE partially mediates the effect of despotic leadership on counterproductive behavior.

\subsection{Moderating role of emotional stability}

According to Judge and Bono (2001), emotional stability is a personality trait. It can be defined as a tendency to be confident, positive, and secure. Individuals with high levels of emotional stability are free from negative emotions. Emotionally stable people have better social skills and behave calmly in stressful situations (Ren, Yunlu, Shaffer, \& Fodchuk, 2015). According to Neff, Toothman, Bowmani, Fox, and Walker (2011), after extraversion, emotional stability is the most widely researched personality trait, and a part of major personality frameworks such as the Big Five and PEN (psychoticism, extroversion, neuroticism). Neuroticism is at the opposite extreme to emotional stability. Neurotics are depressed, oversensitive, and vulnerable, whereas the emotionally stable are calm, cool-tempered, confident, reliable, and peaceful.

A recent wave of studies has established the moderating role of emotional stability (e.g. Bregenzer, Felfe, Bergner, \& Jiménez, 2019; Li, Chun, Ashkanasy, \& Ahlstrom, 2012; Ren et al., 2015). In the leadership domain, Bregenzer et al. (2019) found that emotional stability dampens the effect of abusive leadership on various follower outcomes. Followers with low levels of emotional stability are more fearful of authority and hence are more vulnerable to the abusive behavior of a leader (Thoroughgood, Padilla, Hunter, \& Tate, 2012). Wang, Harms, and Mackey (2015) also observed that neurotics are more influenced by the abusive behavior of those who are emotionally stable. Therefore, those with the emotional stability trait are less receptive of despotic behavior (Bregenzer et al., 2019).

Bregenzer et al. (2019) further argues that followers with low emotional stability do not have effective coping strategies to deal with external harmful influences. In contrast, those with high levels of emotional stability can cope easily with stressful events. Brebner (2001) maintains that the better coping strategies of emotionally stable people help them buffer the impact of negative leadership. They do not allow the consequences to affect them on a personal level and in their work role. According to Sulea, Fine, Fischmann, Sava, and Dumitru (2013), followers with low levels of emotional stability retaliate against abusive leaders by engaging in counterproductive behaviors.

Furthermore, Colbert, Mount, Harter, Witt, and Barrick (2004) believe that there is essentially an interaction between personality and the environment. They contend that the linkage between a negative working environment and counterproductive behaviors depends on the personality traits of the employees. Despotic leaders create an emotionally challenging environment. Individuals who are considerate, patient, secure, and relaxed are more calculated in their reactions to emotionally challenging environments (Langelaan, Bakker, Doornen, \& Schaufeli, 2006). Since emotionally stable individuals have better control over their emotions, they tend to spend their energy on accomplishing tasks and worry less about the toxicity in the environment. In a similar vein, Penney, Hunter, and Perry (2011) found that employees who have high emotional stability do not engage in counterproductive work behaviors.

Based on the above, we propose the following hypothesis:

H3: Emotional stability weakens the effect of despotic leadership on CWB.

\section{Methods and Procedures}

\section{I Participants}

In order to test the hypothesized model, data were gathered from employees working in small and medium enterprises (SMEs) in the Gujranwala Division of Pakistan, from three industrial city districts (Gujranwala, Gujrat, and Sialkot). SMEs were a more relevant context for this study. Most SMEs are primarily family-owned and are run by an owner manager. Employees hold positions and run affairs as directed. There are usually no particular standard operating procedures (SOPs). Therefore, the phenomenon of despotic leadership is deemed to be prevalent in the SME sector. Gujranwala Division covers three of the main industrial districts in Pakistan - Gujranwala, 
Sialkot, and Gujrat - sometimes also referred to as "the Golden Triangle." The main industrial concerns in this region include the leather industry, electronic goods, shoe manufacturing, surgical instruments, and sports goods.

Data were collected from the first line managers and their supervisors. As an ex-ante measure to deal with common method variance, a few precautions were taken. First, the data were collected from supervisor-follower dyads. Second, the responses regarding the predictor and criterion variables were also time-lagged (Podsakoff, MacKenzie, Lee, \& Podsakoff, 2003). Followers reported on despotic leadership behavior of their supervisors, their own reduced organization-based self-esteem, and their emotional stability at $\mathrm{t} 1$ (time 1). Counterproductive behavior of followers was reported by their supervisors at t2 (time 2). The time lag between the two data collection points was 40 days. Workplace activities were normal during this time.

The survey included a cover letter, a section on demographic information, and a section on construct measures. The cover letter briefly explained the research objective, assured anonymity, and offered to share the aggregated results, if required. It is also pertinent to mention that despite most of the respondents speaking Urdu, the questionnaire was not translated since English is a language of instruction and official communication in Pakistan. However, a few modifications were made to the original version in terms of vocabulary wherever these were deemed necessary, provided that such modifications did not disturb the psychometrics of the measures.

A total of 600 survey questionnaires were circulated among supervisor-follower dyads. Each dyad was formed of a 1-1 supervisor-follower pair. The response rate is usually lower in this part of the world and was only $41 \%$ in this case. Out of the 244 questionnaires received, only 227 contained valid responses. Briefly, the sample had the following profile: $61 \%$ males, $39 \%$ females, an average age of 26.8 years, 5.3 years of experience, 4.1 years of tenure, 23\% leather industry, 29\% electronic goods, $18 \%$ shoe manufacturing, $18 \%$ surgical instruments, and $12 \%$ sports goods.

\section{$3 \cdot 2$ Measures}

\subsection{Despotic leadership}

Despotic leadership was measured by six scale items developed by De Hoogh and Den Hartog (2008).
The responses were gathered on a five-point Likert scale (ranging from 1 = strongly disagree to 5 = strongly agree). One of the sample item was "My boss expects unquestioning obedience from employees."

\subsubsection{Reduced organization-based self-esteem (ROBSE)}

ROBSE was measured by ten scale items developed by Pierce et al. (1989) on a five-point Likert scale (ranging from $1=$ strongly disagree to $5=$ strongly agree). For the purpose of measuring reduced OBSE, the items were converted into negatively worded statements. One of the sample items was "I am not counted around here."

\subsubsection{Emotional stability}

The Big Five Inventory (BFI), developed by John, Donahue, and Kentle (1991), was applied to measure emotional stability. It has ten items and the responses were gathered on a five-point Likert scale (ranging from $1=$ strongly disagree to $5=$ strongly agree). One of the sample items reads "I am generally relaxed and can handle stress."

\subsubsection{Counterproductive behavior}

To measure counterproductive behavior, the scale introduced by Bennett and Robinson (2000) was used. It has twenty items and the responses were reported on a five-point Likert scale (ranging from 1 = strongly disagree to $5=$ strongly agree). One of the sample items reads "In this organization the employees act rudely towards others at work."

\section{Analysis and Results}

There data were analyzed in the following steps. First, confirmatory factor analysis (CFA) was conducted to establish the validity and reliability of the measurement model. This included an assessment of the model's fit, reliability, and validity, and common method variance. Second, a descriptive analysis of the data was performed, including the means, standard deviations, and correlations. Third, direct effects were tested using structural regression. Mediation analysis was performed using the bootstrapping technique. Lastly, moderation was tested using the PROCESS macro in SPSS (Hayes, 2012). 


\section{I Confirmatory factor analysis}

\section{I. I Assessment of model fit}

There were four latent constructs in the model: despotic leadership, reduced organization-based self-esteem, counterproductive behavior, and emotional stability. All were first-order constructs, except counterproductive behavior, which had two dimensions. An alternative confirmatory analysis was run in order to obtain the best-fitting model. This approach is also recommended by Shah and Goldstein (2006). In the first run, all measures were loaded to their respective constructs.

In the second run, all measures were loaded on a single construct. The model fit values were within the threshold in the first run (see Table 1). Similarly to the global fit, the local fit was also appropriate. All the factors loaded significantly to their relevant constructs. All loadings were above 0.50 .

\section{I.2 Reliability and validity}

In the next step, it was assessed whether the constructs established reliability and validity. Construct reliability was established through composite reliability, for which a threshold of 0.70 is recommended by Hair, Black, Babin, Anderson, and Tatham (2010). All the constructs had composite reliability. The recommendations of Fornell and Larcker (1981) were followed to assess validity. For convergent validity, the average variances extracted (AVEs) were calculated using all the construct loadings. The AVE for each construct was above 0.50 , which is an indication of convergent validity. Furthermore, discriminant validity was assessed by comparing the square root of the AVEs with the inter-construct correlations. The square roots of the AVEs were above the inter-construct correlations. Therefore, according to the Fornell and Larcker (1981) criterion, all constructs established convergent and discriminant validity.

\section{I.3 Assessment of method bias}

Common method bias threatens the reliability and validity of research results and is a matter of concern. In this research, both ex-ante methodological and ex-post statistical measures were used to control common method bias. Not only were the responses collected from separate sources, but they were also time-lagged, as recommended by Podsakoff et al. (2003). Statistically, the common latent factor method was used to assess method bias. A common factor was added to the confirmatory factor model. The fit indices did not show any significant deviations (CMIN/ $d f=1.636, \mathrm{CFI}=0.921, \mathrm{TLI}=0.901, \mathrm{RMSEA}=0.049$ ). The difference between the factor loadings before and after the addition of the common latent variable was no greater than 0.20 . Hence, there were no indications of method bias in the data.

\subsection{Correlations}

Table 2 below reveals the descriptive results, means, standard deviations, and correlations. All correlations were significant. The bold values in parentheses show the square root of the AVE, which when compared with the inter-construct correlations established construct discriminant validity.

\subsection{Hypotheses testing}

A structural regression was run to test the hypotheses regarding both the direct effect and meditating effects. Control variables for age, gender, qualification, and tenure were also added to the model to account for any variance due to these factors. The model fit was assessed first. The indices showed that both models, i.e. the default model and the control variable model, fit the data well (see Table 3).

\section{Table 1}

\section{Measurement Model Fit}

\begin{tabular}{cccccc}
\hline Model & Structure & CMIN/df & CFI & TLI & RMSEA \\
\hline Model 1 & Hypothesized & 1.783 & 0.971 & 0.963 & 0.051 \\
Model 2 & Single Factor Model & 2.412 & 0.914 & 0.909 & 0.064 \\
Criteria* & & $<3$ & $>0.90$ & $>0.90$ & $<0.08$ \\
\hline
\end{tabular}

Note. $\mathrm{CMIN} / \mathrm{df}=$ normed chi-square, $\mathrm{CFI}=$ comparative fit index, $\mathrm{TLI}=$ Tucker-Lewis index, RMSEA = root mean square of error approximation 
Table 2

\section{Correlations, CR, AVE}

\begin{tabular}{|c|c|c|c|c|c|c|}
\hline \multirow{2}{*}{ Constructs } & \multirow{2}{*}{ CR } & \multirow{2}{*}{ AVE } & \multicolumn{4}{|c|}{ Inter-construct correlations } \\
\hline & & & 1 & 2 & 3 & 4 \\
\hline 1. $\mathrm{CB}$ & 0.812 & 0.611 & $(0.78)$ & $0.523^{* * *}$ & $0.428^{* * *}$ & $-0.307^{* * *}$ \\
\hline 2. DL & 0.823 & 0.724 & & $(0.85)$ & $0.407^{* * *}$ & $-0.399^{* * *}$ \\
\hline 3. ROBSE & 0.913 & 0.702 & & & $(\mathbf{0 . 8 3})$ & $-0.451^{* * *}$ \\
\hline 4. ES & 0.892 & 0.653 & & & & $(\mathbf{0 . 8 0})$ \\
\hline Mean & & & 3.731 & 3.107 & 3.183 & 3.101 \\
\hline SD & & & 0.987 & 1.107 & 1.568 & 1.211 \\
\hline
\end{tabular}

Note. Cut off: $\mathrm{CR}>0.7 ; \mathrm{AVE}>0.50 ; \mathrm{CR}=$ composite reliability, $\mathrm{AVE}=$ average variance extracted, ${ }^{* *} \mathrm{p}<0.001, \mathrm{CB}=$ counterproductive behavior, $\mathrm{DL}=$ despotic leadership, ROBSE = reduced organization-based self-esteem, ES = emotional stability

Table 3

\section{Structural regression model fit}

\begin{tabular}{ccccc}
\hline Model & CMIN/df & CFI & TLI & RMSEA \\
\hline Hypothesized & 1.615 & 0.967 & 0.951 & 0.041 \\
With control variables & 2.071 & 0.932 & 0.921 & 0.050 \\
Cut-off values & CMIN/df $<3$ & CFI $>0.90$ & TLI $>0.90$ & RMSEA<0.08 \\
\hline
\end{tabular}

Nota. Control variables = age, gender, qualification, tenure; $\mathrm{CMIN} / \mathrm{df}=$ normed chi-square, $\mathrm{CFI}=$ comparative fit index, TLI $=$ TuckerLewis index, RMSEA = root mean square of error approximation

Table 4

\section{Hypotheses results}

\begin{tabular}{ccccc}
\hline Dependent variable & Paths & Path coefficient & p-value & $\mathbf{R}^{2}$ \\
\hline Counterproductive Behavior & $\mathrm{DL} \rightarrow \mathrm{CB}$ & 0.346 & 0.001 & 0.321 \\
\hline
\end{tabular}

Note. ${ }^{*} \mathrm{p}<0.05,{ }^{* *} \mathrm{p}<0.01,{ }^{* *} \mathrm{p}<0.001, \mathrm{R}^{2}=$ squared multiple correlation

Table 5

\section{Results for Hypotheses}

\begin{tabular}{|c|c|c|c|c|c|c|}
\hline \multirow{3}{*}{ Effects } & \multicolumn{6}{|c|}{ Counterproductive Behavior } \\
\hline & \multicolumn{6}{|c|}{ BC 95\% CI } \\
\hline & Point of estimate & SE & Lower & Upper & p-value & $\begin{array}{c}\text { Mediation } \\
\text { observed }\end{array}$ \\
\hline Direct effect $(\mathrm{DL} \rightarrow \mathrm{CB})$ & 0.286 & 0.054 & 0.182 & 0.433 & 0.001 & \\
\hline Indirect effect $(\mathrm{DL} \rightarrow \mathrm{ROBSE} \rightarrow \mathrm{CB})$ & 0.042 & 0.024 & 0.018 & 0.093 & 0.015 & \\
\hline Total effect & 0.328 & 0.052 & 0.230 & 0.417 & 0.001 & Partial \\
\hline
\end{tabular}

Note. Mediator $=$ ROBSE, Bootstrapping sample $=2000, \mathrm{BC}=$ bias corrected, $\mathrm{CI}=$ confidence interval

The first hypothesis (H1) stated that DL has a positive effect on counterproductive behavior. The results confirmed the hypothesis. The impact of despotic leadership on counterproductive behavior was significant $(\beta=0.346$, $\mathrm{p}<0.05)$. Despotic leadership explained a variance of $32.1 \%$ in the model $\left(\mathrm{R}^{2}=0.321\right)$ (Table 4$)$.

The second hypothesis $(\mathrm{H} 2)$ stated that ROBSE mediates the effect of DL on counterproductive work behavior. Bootstrapping was conducted in order to test the mediating effects. Bootstrapping was performed with a
95\% bias-corrected confidence interval and 2000 samples. The results showed that the indirect effect was statistically significant $(\beta=0.042, \mathrm{p}<0.001)$ and different from zero (LCI $=0.018, \mathrm{UCI}=0.093)$. Despite the introduction of an indirect path in the model, the direct effect remained significant. Therefore, it is inferred that $\mathrm{H} 2$ was partially supported, that is, reduced organization-based self-esteem has a partial mediating effect (Table 5).

The third hypothesis (H3) stated that emotional stability moderates the effect of DL on CWB in that 
when emotional stability is higher the impact of despotic leadership on CWB is lower. The results showed that high emotional stability interacts with despotic leadership and dampens its effect on counterproductive work behavior $(\beta=-0.383$, $\mathrm{p}<=0.001)$. Moreover, the bootstrapped $95 \%$ bias-corrected confidence interval showed that the results were statistically different from zero (LCI=-0.103, UCI=$0.267)$. Hence, we conclude that moderation is confirmed and accept H3 (Table 6).

\section{Discussion}

This study helps understand the impact of despotic leadership on counterproductive behavior. We also investigated the partial mediating role of reduced organization-based self-esteem between despotic leadership and counterproductive behavior. The study also advances the understanding about the buffering role of personality traits. The interactive effect of despotic leadership and emotional stability on counterproductive behavior was also examined, and the effect was found to be weaker for those with high levels of emotional stability and stronger for those with low levels of emotional stability (Figure 2).

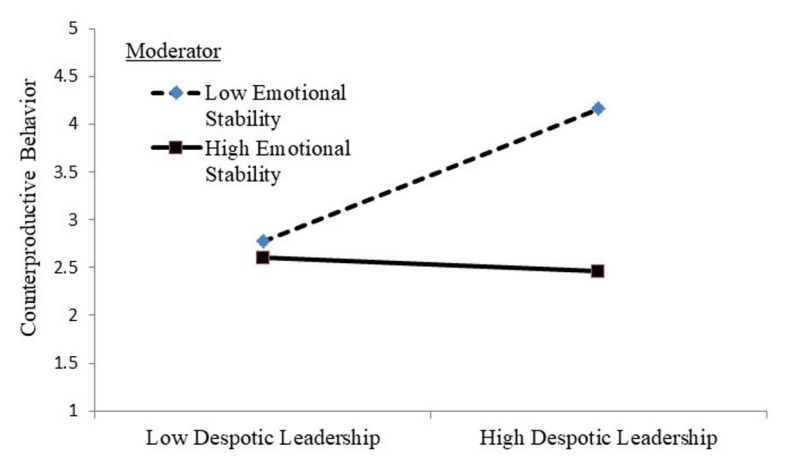

Figure 2. Moderating effect of emotional stability

Table 6

\section{Moderating effects}

\begin{tabular}{|c|c|c|c|c|c|c|}
\hline \multirow{3}{*}{ Hypotheses } & \multirow{3}{*}{ Effects } & \multicolumn{5}{|c|}{ CB } \\
\hline & & \multicolumn{5}{|c|}{ BC $95 \%$ CI } \\
\hline & & Point of estimate & Standard error & Lower & Upper & p-value \\
\hline \multirow[t]{3}{*}{$\mathrm{H}_{3}$} & $\mathrm{DL}$ & 0.311 & 0.067 & 0.199 & 0.433 & 0.001 \\
\hline & ES & -0.467 & 0.071 & -0.317 & -0.577 & 0.001 \\
\hline & DL $x \mathrm{ES}$ & -0.383 & 0.042 & -0.103 & -0.267 & 0.001 \\
\hline
\end{tabular}

Note. $\mathrm{CWB}=$ counterproductive behavior, $\mathrm{DL}=$ despotic leadership, $\mathrm{ES}=$ emotional stability, ROBSE = reduced organization base self esteem 
In previous studies, it has been found that emotionally stable employees neither care about negative leadership nor do they engage in counterproductive work behavior (Halbesleben, Harvey, \& Bolino, 2009; Penney et al., 2011; Perry, Penney, \& Witt, 2008; Zellars, Perrewé, Hochwarter, \& Anderson, 2006).

\subsection{Practical implications}

This study has implications for managerial policy and practice. One significant implication is that despotic leadership has a negative impact on the productivity of followers. It is important for organizations to devise mechanisms for recruiting and training supervisors where their despotic tendencies are identified. Leaders with a strong desire for power use their influence to abuse their followers. The abused followers then engage in activities that are counterproductive. Organizations are advised to follow a three-pronged strategy to guard against despotic leadership practices. First, recruitment procedures should be revamped (Nauman et al., 2018). Various personality assessment tests should be conducted to identify the leadership qualities of incumbent leaders. Second, in the case of internally recruiting supervisors, a reliable succession plan should be established. Those listed in the succession plan should be put under constant surveillance for their behavior in relation to others before they are placed in a position of authority. Third, organizations should develop an appeals process. Followers should be encouraged to report demanding behavior by their leaders to the relevant forums in order for appropriate actions to be taken.

OBSE was also proven to partially mediate between despotic leadership and counterproductive behavior. One of the immediate outcomes through which other consequences occur is that the followers of a despotic leader lose their sense of self-worth. When their self-worth is shaken, employees are not motivated to perform their duties and become emotionally exhausted. Such employees are more likely to burn out and leave the company. In certain situations, the effects of despotic leadership have also been reported to cascade into family life (e.g. Nauman et al., 2018). Given this backdrop, it is even more important for a manager to care for their followers' sense of self-worth. Leaders should be watchful of their choice of words and actions. Any demanding behavior by leaders would be detrimental to their followers and should be avoided.
On the other hand, regardless of the efforts made by organizations, there can still remain a possibility for despotic behaviors to take place. People adopt one attitude when they are in line waiting for authority to be assigned; however, once they accrue power, they may adopt despotic behaviors. Organizations should use personality assessment tests for followers as well. Preference should be given to the emotionally stable. Emotionally stable individuals have been found to ignore despotic behavior and not engage in counterproductive behaviors. Organizations should also organize training sessions to highlight to employees the difference between individual self-interests and organizational interests. Employees should be aware of how to prioritize organizational interests over individual interests.

\subsection{Limitations and future research}

Some limitations may affect the generalizability of the findings of this research. First, a cross-sectional design was used to collect the data. Despite the introduction of a temporal order of precedence, of 40 days, for the independent and dependent variables in the data collection, the cross-sectional design cannot yet be claimed to establish causality. A longitudinal design in future studies would serve this purpose better. Moreover, we collected dyadic responses. Supervisors reported the counterproductive behavior of followers. Followers reported despotic leadership and reduced organization-based self-esteem. Though this technique handles self-serving bias, it is also prone to deflated responses. Therefore, future studies could further refine the study design. Both supervisors and followers could report their own and others' behavior. Lastly, as the direct relationship between despotic leadership and counterproductive behavior was sufficiently substantiated, other intervening mechanisms should be further explored. In the future, it could be considered whether personality traits and psychological resources are moderators between despotic leadership and counterproductive behavior.

\section{References}

Aronson, E. (2001). Integrating leadership styles and ethical perspectives. Canadian Journal of Administrative Sciences / Revue Canadienne Des Sciences de l'Administration, 18(4), 244-256. https://doi.org/10.1111/j.1936-4490.2001. tb00260.x 
Ashforth, B. E. (2009). Petty tyranny in organizations: A preliminary examination of antecedents and consequences. Canadian Journal of Administrative Sciences / Revue Canadienne Des Sciences de l'Administration, 14(2), 126-140. https:// doi.org/10.1111/j.1936-4490.1997.tb00124.x

Baumeister, R. F. (1999). The self in social psychology. Philadelphia: Psychology Press.

Baumeister, R. F., Dewall, C. N., Ciarocco, N. J., \& Twenge, J. M. (2005). Social exclusion impairs self-regulation. Journal of Personality and Social Psychology, 88(4), 589-604. https://doi.org/10.1037/0022-3514.88.4.589

Bennett, R. J., \& Robinson, S. L. (2000). Development of a measure of workplace deviance. Journal of Applied Psychology, 85(3), 349-360.

Blau, P. M. (1964). Exchange and power in social life. New York: Routledge.

Bowling, N. A., Eschleman, K. J., Wang, Q., Kirkendall, C., \& Alarcon, G. (2010). A meta-analysis of the predictors and consequences of organization-based self-esteem. Journal of Occupational and Organizational Psychology, 83(3), 601-626. https://doi.org/10.1348/096317909X454382

Brebner, J. (2001). Personality and stress coping. Personality and Individual Differences, 31(3), 317-327. https://doi. org/10.1016/S0191-8869 (00)00138-0

Bregenzer, A., Felfe, J., Bergner, S., \& Jiménez, P. (2019). How followers' emotional stability and cultural value orientations moderate the impact of health-promoting leadership and abusive supervision on health-related resources. German Journal of Human Resource Management, 33(4), 307-336. https://doi.org/10.1177/2397002218823300

Carlson, D., Ferguson, M., Perrewé, P. L. \& Whitten, D. (2009). The fallout from abusive supervision through work-family conflict: An examination of job incumbents and their parents. Personnel Psychology, 64(4), 937-96. doi:10.1111/j.1744-6570.2011.01232.x

Chan S. C. H., Huang, X., Snape, E., \& Lam, C. K. (2013). The Janus face of paternalistic leaders: Authoritarianism, benevolence, subordinates' organization-based self-esteem, and performance. Journal of Organizational Behavior, 34, 108-128. https://doi.org/10.1002/job.1797
Colbert, A. E., Mount, M. K., Harter, J. K., Witt, L. A., $\&$ Barrick, M. R. (2004). Interactive effects of personality and perceptions of the work situation on workplace deviance. Journal of Applied Psychology, 89(4), 599-609.

Collins, M. D., \& Jackson, C. J. (2015). A process model of self-regulation and leadership: How attentional resource capacity and negative emotions influence constructive and destructive leadership. The Leadership Quarterly, 26(3), 386-401.

Cropanzano, R., \& Mitchell, M. (2005). Social exchange theory: An interdisciplinary review. Journal of Management, 31(6), 874-900. https://doi.org/10.1177/0149206305279602

De Hoogh, A. H. B. B., \& Den Hartog, D. N. (2008). Ethical and despotic leadership, relationships with leader's social responsibility, top management team effectiveness and subordinates' optimism: A multi-method study. The Leadership Quarterly, 19(3), 297-311. https://doi. org/10.1016/j.leaqua.2008.03.002

Einarsen, S., Aasland, M. S., \& Skogstad, A. (2007). Destructive leadership behaviour: A definition and conceptual model. The Leadership Quarterly, 18(3), 207-216.

Emerson, R. M. (1976). Social exchange theory. Annual Review of Sociology, 2(1), 335-362.

Erkutlu, H., \& Chafra, J. (2018). Despotic leadership and organizational deviance: The mediating role of organizational identification and the moderating role of value congruence. Journal of Strategy and Management, 11(2), 150-165.

Ferris, D. L., Brown, D. J., \& Heller, D. (2009). Organizational supports and organizational deviance: The mediating role of organization-based self-esteem. Organizational Behavior and Human Decision Processes, 108(2), 279-286. https:// doi.org/10.1016/j.obhdp.2008.09.001

Fida, R., Paciello, M., Tramontano, C., Fontaine, R. G., Barbaranelli, C., \& Farnese, M. L. (2015). An integrative approach to understanding counterproductive work behavior: The roles of stressors, negative emotions, and moral disengagement. Journal of Business Ethics, 130(1), 131-144. https://doi.org/10.1007/s10551-014-2209-5 
Fornell, C., \& Larcker, D. F. (1981). Evaluating structural equation models with unobservable variables and measurement error. Journal of Marketing Research, 18(1), 39. https://doi.org/10.2307/3151312

Frost, P. J. (2004). Handling toxic emotions: New challenges for leaders and their organization. Organizational Dynamics, 33(2), 111-127. https://doi.org/10.1016/j. orgdyn.2004.01.001

Gardner, D. G., \& Pierce, J. L. (2016). Organization-based self-esteem in work teams. Group Processes \& Intergroup Relations, 19(3), 394-408.

Gardner, D. G., Dyne, L., \& Pierce, J. L. (2004). The effects of pay level on organization-based self-esteem and performance: A field study. Journal of Occupational and Organizational Psychology, 77(3), 307-322. https://doi. org/10.1348/0963179041752646

Gouldner, A. W. (1960). The norm of reciprocity: A preliminary statement. American Sociological Review, 25(2), 161. https://doi.org/10.2307/2092623

Griffin, R. W., \& O'Leary-Kelly, A. M. (2004). The dark side of organizational behavior. San Francisco: Jossey-Bass.

Gruys, M. L., \& Sackett, P. R. (2003). Investigating the dimensionality of counterproductive work behavior. International Journal of Selection and Assessment, 11(1), 30-42. https://doi.org/10.1111/1468-2389.00224

Hair, J. F., Black, W. C., Babin, B. J., Anderson, R. E., \& Tatham, R. L. (2010). Multivariate data analysis. Upper Saddle River New Jersey: Pearson.

Halbesleben, J. R. B., Harvey, J., \& Bolino, M. C. (2009). Too, engaged? A conservation of resources view of the relationship between work engagement and work interference with family. Journal of Applied Psychology, 94(6), 1452-1465.

Hayes, A. F. (2012). PROCESS: A versatile computational tool for observed variable mediation, moderation, and conditional process modeling [White paper]. Retrieved from https://www.researchgate.net/profile/Ludmila_ZajacLamparska/post/How_can_I_analyze_baseline_measures_ as_predictors_of_change_in_longitudinal_designs/attac
hment/59d61de779197b807797c2a0/AS:27384349770 1387@1442300786437/download/Hayes+process.pdf

Heppner, P., Cook, S., \& Wright, D. M. (1995). Progress in resolving problems: A problem-focused style of coping. Journal of Counseling, 42(3), 279-293. Retrieved from https://psycnet.apa.org/record/1995-42425-001

Howell, J. M., \& Avolio, B. J. (1992). The ethics of charismatic leadership: Submission or liberation? Academy of Management Perspectives, 6(2), 43-54.

John, O. P., Donahue, E. M., \& Kentle, R. L. (1991). The big five inventory (4th ed.). Berkeley, CA: University of California, Berkeley, Institute of Personality and Social Research.

Judge, T., \& Bono, J. (2001). Relationship of core selfevaluations traits—self-esteem, generalized self-efficacy, locus of control, and emotional stability — with job satisfaction and job performance. Journal of Applied Psychology, 86(1), 80-92. Retrieved from https://psycnet.apa.org/journals/ apl/86/1/80.html?uid=2001-16970-007

Karakitapoğlu-Aygün, Z., \& Gumusluoglu, L. (2013). The bright and dark sides of leadership: Transformational vs. non-transformational leadership in a non-Western context. Leadership, 9(1), 107-133. https://doi. org/10.1177/1742715012455131

Kelley, H. H. (1968). Interpersonal accommodation. American Psychologist, 23(6), 399-410. doi: https://doi. org/10.1037/h0026482

Korman, A. K. (1970). Toward a hypothesis of work behavior. Journal of Applied Psychology, 54(Pt, 1), 31-41.

Korman, A. K. (1971). Organizational achievement, aggression and creativity: Some suggestions toward an integrated theory. Organizational Behavior and Human Performance, 6(5), 593-613. Retrieved from https://www. sciencedirect.com/science/article/pii/S0030507371800090

Langelaan, S., Bakker, A. B., Doornen, L. J., \& Schaufeli, W. B. (2006). Burnout and work engagement: Do individual differences make a difference? Personality and Individual Differences, 40(3), 521-532. Retrieved from https://www.sciencedirect.com/science/article/pii/ S0191886905002679 
Lee, J., \& Peccei, R. (2007). Perceived organizational support and affective commitment: The mediating role of organization-based self-esteem in the context of job insecurity. Journal of Organizational Behavior, 28(6), 661-685. doi: https://doi.org/10.1002/job.431

Li, Y., Chun, H., Ashkanasy, N. M., \& Ahlstrom, D. (2012). A multi-level study of emergent group leadership: Effects of emotional stability and group conflict. Asia Pacific Journal of Management, 29(2), 351-366. doi: https://doi.org/10.1007/s10490-012-9298-4

Morgeson, F. P., DeRue D. S., \& Karam, E. P. (2010). Leadership in teams: A functional approach to understanding leadership structures and processes. Journal of Management, 36(1), 5-39.

Naseer, S., Raja, U., Syed, F., Donia, M. B. L., \& Darr, W. (2016). Perils of being close to a bad leader in a bad environment: Exploring the combined effects of despotic leadership, leader member exchange, and perceived organizational politics on behaviors. The Leadership Quarterly, 27(1), 14-33.

Nauman, S., Fatima, T., \& Haq, I. U. (2018). Does despotic leadership harm employee family life: Exploring the effects of emotional exhaustion and anxiety. Frontiers in Psychology, 9, 601. doi: https://doi.org/10.3389/ fpsyg.2018.00601

Neff, M., Toothman, N., Bowmani, R., Fox, J. E., \& Walker, M. (2011). Don't scratch! Self-adaptors reflect emotional stability. In H. H. Vilhjálmsson, S. Kopp, M. Marsella, \& K. R., Thórisson (Eds.), Intelligent Virtual Agents (pp.398-411). Berlin, Hiedelberg: Springer.

Norman, S. M., Gardner, D. G., \& Pierce, J. L. (2015). Leader roles, organization-based self-esteem, and employee outcomes. Leadership and Organization Development Journal, 36(3), 253-270. https://doi.org/10.1108/LODJ06-2013-0072

Penney, L. M., Hunter, E. M., \& Perry, S. J. (2011). Personality and counterproductive work behaviour: Using conservation of resources theory to narrow the profile of deviant employees. Journal of Occupational and Organizational Psychology, 84(1), 58-77. https://doi. org/10.1111/j.2044-8325.2010.02007.x
Perry, S. J., Penney, L. M., \& Witt, L. A. (2008). Coping with the constraints of self-employment: A personsituation model of entreprneurial burnout. Academy of Management Proceedings, 2008(1), 1-6. doi:10.5465/ AMBPP.2008.33636328

Pierce, J. L., \& Gardner, D. G. (2004). Self-esteem within the work and organizational context: A review of the organization-based self-esteem literature. Journal of Management, 30(5), 591-622. https://doi.org/10.1016/j. jm.2003.10.001

Pierce, J. L., Gardner, D. G., Cummings, L. L., \& Dunham, R. B. (1989). Organization-based self-esteem: Construct definition, measurement, and validation. Academy of Management Journal, 32(3), 622-648.

Podsakoff, P. M., MacKenzie, S. B., Lee, J. Y., \& Podsakoff, N. P. (2003). Common method biases in behavioral research: A critical review of the literature and recommended remedies. Journal of Applied Psychology, 88(5), 879-903. Retrieved from http://doi.apa.org/ journals/apl/88/5/879.html

Ren, H., Yunlu, D. G., Shaffer, M., \& Fodchuk, K. M. (2015). Expatriate success and thriving: The influence of job deprivation and emotional stability. Journal of World Business, 50(1), 69-78.

Richman, J. A., Flaherty, J. A., Rospenda, K. M., \& Christensen, M. L. (1992). Mental health consequences and correlates of reported medical student abuse. Jama Network, 267(5), 692-694.

Robinson, S. L., \& Bennett, R. J. (1995). A typology of deviant workplace behaviors: A multidimensional scaling study. Academy of Management Journal, 38(2), 555-572.

Sackett, P. R., \& DeVore, C. J. (2002). Counterproductive behaviors at work: In N. Anderson., D. S. Ones, H. K. Sinangil, \& C. Viswesvaran (Eds.), Handbook of Industrial, Work and Organizational Psychology (Vol. 1, pp. 145-164). Thousand Oaks, CA: Sage Publications Ltd.

Schilling, J. (2009). From ineffectiveness to destruction: A qualitative study on the meaning of negative leadership. Leadership, 5(1), 102-128. 
Schyns, B., \& Schilling, J. (2013). How bad are the effects of bad leaders? A meta-analysis of destructive leadership and its outcomes. The Leadership Quarterly, 24(1), 138-158.

Shah, R., \& Goldstein, S. M. (2006). Use of structural equation modeling in operations management research : Looking back and forward. Journal of Operations Management, 24(2), 148-169. https://doi.org/10.1016/j. jom.2005.05.001

Smith, T. W., \& Williams, P. G. (1992). Personality and health: Advantages and limitations of the five-factor model. Journal of Personality, 60(2), 395-425. https:// doi.org/10.1111/j.1467-6494.1992.tb00978.x

Spector, P. E., Fox, S., Penney, L. M., Bruursema, K., Goh, A., \& Kessler, S. (2006). The dimensionality of counterproductivity: Are all counterproductive behaviors created equal? Journal of Vocational Behavior, 68(3), 446-460.

Sulea, C., Fine, S., Fischmann, G., Sava, F. A., \& Dumitru, C. (2013). Abusive supervision and counterproductive work behaviors: The moderating effects of personality. Journal of Personnel Psychology, 12(4), 196-200. https:// doi.org/10.1027/1866-5888/a000097

Tepper, B. J. (2000). Consequences of abusive supervision. Academy of Management Journal, 43(2), 178-190.

Tepper, B. J. (2007). Abusive supervision in work organizations: Review, synthesis, and research agenda. Journal of Management, 33(3), 261-289. https://doi. org/10.1177/0149206307300812

Tepper, B. J., Carr, J. C., Breaux, D. M., Geider, S., Hu, C., \& Hua, W. (2009). Abusive supervision, intentions to quit, and employees' workplace deviance: A power/ dependence analysis. Organizational Behavior and Human Decision Processes, 109(2), 156-167. Retrieved from https://www.sciencedirect.com/science/article/pii/ S0749597809000351

Thau, S., Derfler-Rozin, R., Pitesa, M., Mitchell, M. S., \& Pillutla, M. M. (2015). Unethical for the sake of the group: Risk of social exclusion and pro-group unethical behavior. Journal of Applied Psychology, 100(1), 98-113.

Thoroughgood, C. N., Padilla, A., Hunter, S. T., \& Tate, B. W. (2012). The susceptible circle: A taxonomy of followers associated with destructive leadership. The Leadership Quarterly, 23(5), 897-917. Retrieved from https://www.sciencedirect.com/science/article/pii/ S1048984312000471

Vecchio, R. P. (2000). Negative emotion in the workplace: Employee jealousy and envy. International Journal of Stress Management, 7(3), 161-179. https:// doi.org/10.1023/A:1009592430712

Vries, R. E., de, (2018). Three nightmare traits in leaders. Frontiers in Psychology, 9, 871. doi: https://doi.org/10.3389/ fpsyg.2018.00871

Wang, G., Harms, P. D., \& Mackey, J. D. (2015). Does it take two to tangle? Subordinates' perceptions of and reactions to abusive supervision. Journal of Business Ethics, 131(2), 487-503. https://doi.org/10.1007/s10551-0142292-7

Zellars, K. L., Perrewé, P. L., Hochwarter, W. A., \& Anderson, K. S. (2006). The interactive effects of positive affect and conscientiousness on strain. Journal of Occupational Health Psychology, 11(3), 281-289. 


\section{Financial support:}

There are no funding agencies to report.

\section{Conflicts of interest:}

The authors have no conflict of interest to declare.

\section{Copyrights:}

RBGN owns the copyrights of this published content.

\section{Plagiarism analysis:}

RBGN performs plagiarism analysis on all its articles at the time of submission and after approval of the manuscript using the iThenticate tool.

\section{Authors:}

1. Muhammad Anwar ul Haq, PhD, University of Gujrat, Gujrat, Pakistan. anwar.haq@uog.edu.pk

2. Mirza Ashfaq Ahmed, PhD, University of Gujrat, Gujrat, Pakistan. ashfaq.ahmed@uog.edu.pk

3. Sobia Shabbir, MBA, University of Gujrat, Gujrat, Pakistan. sobiashabbir10@gmail.com

4. Shaista Khalid, PhD, University of Sargodha, Gujrat, Pakistan. shaista.khalid@uos.edu.pk

\section{Authors' Contributions:}

$\mathbf{1}^{\text {st }}$ author: definition of research problem; development of hypotheses or research questions (empirical studies); theoretical foundation/literature review; definition of methodological procedures; analysis and interpretation of data; manuscript writing; addressing review correspondence and comments.

$\mathbf{2}^{\text {nd }}$ author: definition of research problem; definition of methodological procedures; literature review; statistical analysis; analysis and interpretation of data; critical revision of the manuscript.

$3^{\text {rd }}$ author: definition of problem statement; development of theoretical propositions (theoretical work); definition of methodological procedures; literature review; manuscript writing.

$4^{\text {th }}$ author: definition of problem statement; data collection; critical revision of the manuscript; proof-reading. 